University of Nebraska - Lincoln

DigitalCommons@University of Nebraska - Lincoln

1984

\title{
Herbivore Effect on Stature, Fruiting, and Leaf Dynamics of a Native Crucifer
}

Svata M. Louda

University of Nebraska - Lincoln, slouda1@unl.edu

Follow this and additional works at: https://digitalcommons.unl.edu/bioscilouda

Part of the Ecology and Evolutionary Biology Commons

Louda, Svata M., "Herbivore Effect on Stature, Fruiting, and Leaf Dynamics of a Native Crucifer" (1984). Svata M. Louda Publications. 15.

https://digitalcommons.unl.edu/bioscilouda/15

This Article is brought to you for free and open access by the Papers in the Biological Sciences at DigitalCommons@University of Nebraska - Lincoln. It has been accepted for inclusion in Svata M. Louda Publications by an authorized administrator of DigitalCommons@University of Nebraska - Lincoln. 


\title{
HERBIVORE EFFECT ON STATURE, FRUITING, AND LEAF DYNAMICS OF A NATIVE CRUCIFER ${ }^{1}$
}

\author{
Sva ̌̌a M. LOUdA ${ }^{2}$ \\ Duke University Marine Laboratory, Beaufort, North Carolina 28516, \\ Department of Botany, Duke University, Durham, North Carolina 27706, and \\ Rocky Mountain Biological Laboratory, Gothic, Colorado 81224 USA
}

\begin{abstract}
The impact of a native, leaf-feeding chrysomelid beetle (Phaedon sp. nr. oviformis) on bittercress (Cardamine cordifolia: Cruciferae), was evaluated in an exclusion experiment. Multivariate statistical analysis showed a significant increase in plant performance in the rotenone exclusion compared to performance in the paired control treatment. Plant response to the reduction of herbivory was a complicated, interrelated syndrome of changes. When insects were excluded, the amount of missing leaf area decreased significantly (3.6-fold; $3.2-0.9 \mathrm{~cm}^{2}$ per plant), and the total leaf area increased 5.7-fold $\left(12.9-73.4 \mathrm{~cm}^{2}\right.$ per plant). Plant height $(5.7-20.3 \mathrm{~cm})$ and fruit production $(0.1-$ 3.9 siliques per plant) also increased significantly when the number of insects was reduced. Furthermore, the $570 \%$ expansion in leaf area due to the exclusion of insects involved significant increases both in the initiation of new leaves and in the survival of mature leaves. Nevertheless, insect herbivory at a level well below complete defoliation ( $25 \%$ of the leaf area) changed leaf demography (both phenology and dynamics) and reduced plant performance by decreasing the plant stature, leaf area, and fruit production of this native forb. Thus, further experimental assessment is necessary before generalizations can be made regarding the effects of herbivory on plant dynamics.
\end{abstract}

Key words: bittercress; Cardamine cordifolia; Chrysomelidae; Cruciferae; herbivory; insect-plant interactions; leaf demography; leaf phenology; parasitism; Phaedon; plant population dynamics.

\section{INTRODUCTION}

Insect herbivory is a ubiquitous and often significant selective pressure on plants (see reviews in Harris 1973, Harper 1977, Hodkinson and Hughes 1982). Comprehensive evidence of the effects of insects on plant growth and reproduction exists for some herbaceous agronomic species (e.g., Harcourt 1970). However, the impact of foliage-feeding insects on the performance and demography of native host-plant species is still unresolved (Owen and Wiegert 1976, Stenseth 1978, Janzen 1979).

Compared with the total photosynthetic area of a plant, the area eaten by insects usually appears to be small (1-30\%) (Mattson and Addy 1975). In fact, the rarity of defoliation is often considered an argument against the importance of insect herbivory in plant dynamics under normal circumstances (e.g., Harris 1973, Mattson and Addy 1975, Owen and Wiegert 1976). This argument relies on adequate observational data, such as estimates of missing leaf area or of annual primary production removed, to assess herbivore effect (Janzen 1979). However, the overall effect of herbivory may be more complicated and subtle. For example, insects can remove whole leaves, and often do decrease plant growth (Morrow and LaMarche 1978, Whittaker $1979,1982)$ as well as diminish the energy available for seed production (e.g., Rockwood 1973, Waloff and Richards 1977). Thus, post hoc quantification of miss-

\footnotetext{
${ }^{1}$ Received 4 May 1983; revised 9 July 1983; accepted 16 October 1983.

${ }^{2}$ Present address: School of Biological Sciences, University of Nebraska, Lincoln, Nebraska 68588 USA.
}

ing or damaged leaf area may often be inadequate for assessing the real or total cost of damage (Janzen 1979). Unfortunately, the requisite experimentation, testing the trade-off between the benefits and costs of insectinduced losses in performance and fitness of native herbaceous plants, is still uncommon (see reviews in Harper 1969, 1977, Janzen 1979, Whittaker 1979). Janzen (1979), in fact, suggested that the accurate evaluation of the impact of herbivory in plant dynamics "involves the most difficult question in evolutionary biology, population biology, and ecology."

The consequences of chronic foliage losses caused by insect feeding have been assessed experimentally for only a few native, nontree plants (see Janzen 1979, Whittaker 1979). The available field experiments demonstrate significant but subtle detrimental effects of low-level foliage losses on the dynamics of those herbaceous plants (Cantlon 1969, Manley et al. 1975, Waloff and Richards 1977, Bentley and Whittaker 1979, Rausher and Feeny 1980, Parker and Root 1981, Rausher 1981, Parker 1982, Whittaker 1982). However, other observations suggest that sublethal losses of foliage caused by herbivores are either neutral (e.g., Wiegert and Owen 1971, Harris 1973) or positive for relative plant performance (Owen and Wiegert 1976, Simberloff et al. 1978, Stenseth 1978, McNaughton 1979, Dyer et al. 1982). To test the predictions and verify the specific outcomes, additional experimentally derived data are needed on more species (Janzen 1979, Chabot and Hicks 1982), particularly in relation to different life histories, habitats, and environmental conditions.

Consequently, I studied insect herbivory on Car- 
damine cordifolia (bittercress), an herbaceous, perennial mustard (Cruciferae) that occurs throughout the Rocky Mountain cordillera at an elevation of between 2150 and $3550 \mathrm{~m}$ (Harrington 1954). Bittercress grows in moist ground along streams or in meadows, usually in the shade of spruce (Picea spp.) or willow (Salix spp.; Barrell 1969). The dispersion pattern of $C$. cordifolia in this region reflects the patchiness of moist, shaded microhabitats as well as the plant's vegetative expansion via short, slender rhizomes.

\section{MeThODS}

An isolated streamside cluster of $C$. cordifolia under a small stand of spruce was observed quantitatively between 1979 and 1981. Most of the plants exhibited some insect damage. In early July 1979, damage occurred, on an average, on $56 \%$ of the leaves of each of 25 sampled plants. Adult chrysomelids were in the terminal cluster of leaves of many plants. Few other insects were present. For example, on 4 July 1980, I carefully searched 25 plants and found 10 chrysomelids and one adult psyllid (Aphalara sp. nov.). Furthermore, the only other crucifer-feeding insect observed, the weevil Ceutorhynchus pusio, was rare ( $\leq 1$ sighting per census). By late August, no chrysomelid adults remained, and $>99 \%$ of the leaves on these plants exhibited damage. Interestingly, both magnitude of leaf damage and insect occurrence were inversely related to glucosinolate concentration at this site (Louda and Rodman $1983 a, b$ ). Furthermore, feeding damage to the apical meristem, terminal leaves, and top of the stem was extensive. The number of terminals destroyed increased from 20 to $70 \%$ between early July and late August in 1979 and from 24 to $80 \%$ over the same period in 1980. Destruction of the terminal was the result of beetles feeding on and through the stem supporting the apical meristem and its two to four developing leaves. Such damage arrested vertical growth and precluded successful flowering by the plant.

The aim of my field experiment was to evaluate experimentally the quantitative effects of feeding by the chrysomelid beetle, Phaedon sp. nr. oviformis Lec. (Chrysomelinae, Phaedonini), on the performance of this native crucifer under the conditions at this site. The performance of control plants, subjected to naturally occurring levels of insect utilization, was compared with adjacent, equal-sized plants that were treated biweekly with rotenone. I addressed two main questions: (1) Does the damage by adult chrysomelid beetles affect the growth or fruit production of $C$. cordifolia? (2) What other effects, if any, does the damage caused by an adapted insect herbivore have on plant traits or leaf dynamics?

This experiment was conducted in 1981 at a site ("First Streamlet" [FS], $3070 \mathrm{~m}$ elevation) at which extensive damage had been observed and for which preliminary data were available. The site is in the Copper Creek drainage (2990-3550 m), above the Rocky
Mountain Biological Laboratory (RMBL) in Gothic, $9.6 \mathrm{~km}$ northwest of Crested Butte, Gunnison County, Colorado, USA. The frost-free growing period usually occurs from late May through late August (Chew 1975, 1977). Plants with ramets up to $30-75 \mathrm{~cm}$ high often grow in distinct stands in this area. In this paper I use "plant" to refer to an obviously isolated ramet. Flowering in the study region occurs from late June through July. Fruit set and maturation occur in August and early September, near the end of the growing season.

Cardamine cordifolia was locally abundant in the study region and was utilized regularly by $>20$ phytophagous insect taxa (S. M. Louda, personal observation), including the leaf-feeding chrysomelid beetle Phaedon sp. nr. oviformis; a mustard weevil, Ceutorhynchus pusio (Curculionidae); a diamondback moth, Plutella xylostella (Plutellidae); a homopteran, Aphalara sp. nov. (Psyllidae); and a leaf-mining fly, Melanagromyza sp. (Agromyzidae). The chrysomelid beetle was consistently the most common herbivore and was responsible for most of the leaf and stem damage observed at the FS site during the two previous growing seasons. Early observations suggested that the chrysomelid beetles might have a quantitative effect. Further, the initial data provided comparative information for plant performance between years.

\section{Exclusion}

On 31 May 1981, 20 isolated ramets of all available sizes were paired by height and measured. Each plant within a pair was assigned randomly to one of two treatments: (1) spray application of rotenone insecticide dissolved in water, or (2) spray of water only (the control). Rotenone, an isoflavonoid with an isopentenyl substitution (Harborne 1979), was chosen in order to avoid the potential complication of any stimulation of plant growth by nitrogen-containing systemic insecticides (Wallace 1961). Flavonoids are polyphenolics, containing only $\mathrm{C}, \mathrm{H}$, and $\mathrm{O}$; they may bind to other classes of plant constitutents such as proteins (Harborne 1979). Treatments were initially applied on 31 May 1981 and were repeated once every $2 \mathrm{wk}$ through 30 July ( $8 \mathrm{wk}$ ), by which time results were clear. Additional applications of the treatments were made in June, after each of two heavy rains.

Measurements included the following: (1) ramet height (in centimetres), (2) number of basal and cauline leaves, (3) individual leaf lengths, (4) insect occurrence, (5) area missing per leaf, (6) unusual color or condition of the leaf, and (7) reproductive development. The missing area was quantified by comparison to a grid with $1-\mathrm{mm}^{2}$ squares. The total area per leaf was estimated by using leaf length and a relationship of area to length that had been determined previously using a LI-COR leaf-area meter (area $=0.499 \times$ length $^{2}, R^{2}=$ $0.895, N=47$ ). Sampling was conducted first biweekly and then monthly (31 May, 14 June, 2 July, and 30 July 1981). Subsequent observations on experimental 
TABLE 1. Differences between rotenone-sprayed individuals and water-sprayed control plants in individual parameters of plant performance for Cardamine cordifolia at First Streamlet, Copper Creek, Gothic, Colorado. Experiment initiated 31 May 1981 and terminated 30 July 1981.

\begin{tabular}{|c|c|c|c|c|}
\hline & \multicolumn{2}{|c|}{ Control† } & \multicolumn{2}{|c|}{$\begin{array}{l}\text { Herbivore } \\
\text { exclusion } \dagger\end{array}$} \\
\hline & $\bar{x}$ & SE & $\bar{x}$ & $\mathrm{SE}$ \\
\hline \multicolumn{5}{|l|}{ Initial } \\
\hline \multicolumn{5}{|l|}{ Basal leaves/plant } \\
\hline Number & 2.6 & 0.70 & 2.3 & 0.47 \\
\hline Leaf area $\left(\mathrm{cm}^{2}\right) \ddagger$ & 2.8 & 0.95 & 1.5 & 0.42 \\
\hline Insect damage $\left(\mathrm{mm}^{2}\right) \S$ & 3.3 & 1.54 & 4.8 & 1.31 \\
\hline \multicolumn{5}{|l|}{ Cauline leaves/plant } \\
\hline Number & 5.2 & 1.20 & 4.4 & 0.97 \\
\hline Leaf area $\left(\mathrm{cm}^{2}\right) \ddagger$ & 2.3 & 0.80 & 2.3 & 0.96 \\
\hline Insect damage $\left(\mathrm{mm}^{2}\right) \S$ & 2.6 & 1.38 & 2.5 & 1.46 \\
\hline \multicolumn{5}{|l|}{ Final } \\
\hline \multicolumn{5}{|l|}{ Basal leaves/plant } \\
\hline Number & 1.4 & 0.62 & 9.5 & 2.15 \\
\hline Leaf area $\left(\mathrm{cm}^{2}\right) \ddagger$ & 3.6 & 1.93 & 22.8 & 8.99 \\
\hline Insect damage $\left(\mathrm{mm}^{2}\right) \S$ & 122.2 & 31.83 & 31.4 & 7.04 \\
\hline \multicolumn{5}{|l|}{ Cauline leaves/plant } \\
\hline Number & 2.6 & 1.07 & 13.3 & 2.01 \\
\hline Leaf area $\left(\mathrm{cm}^{2}\right) \ddagger$ & 9.3 & 3.59 & 50.6 & 18.99 \\
\hline Insect damage $\left(\mathrm{mm}^{2}\right) \S$ & 198.3 & 39.89 & 61.7 & 11.83 \\
\hline \multicolumn{5}{|l|}{ Siliques/plant $\|$} \\
\hline Number & 0.1 & 0.01 & 3.9 & 1.20 \\
\hline
\end{tabular}

$\dagger N=9$ plants/treatment; Hotelling's $T^{2}$ test of $\log (x+1)-$ transformed differences between treatments in change over 8 wk for the seven vegetative parameters (see Exclusion section of Methods), $T^{2}=145.68, P<.001$.

¥ Estimated from leaf area $(A)$ to leaf length $(L)$ relationship on undamaged leaves $\left(N=47, A=0.499 L^{2}, r^{2}=0.895\right)$.

$\S$ Measured as total leaf area $\left(\mathrm{mm}^{2}\right)$ of holes and leaf margin missing per plant due to feeding by mandibulate insects.

\| Silique = long slender fruit of the Cruciferae; inflated siliques averaged 6.0 seeds ( $\mathrm{SE}=0.36, N=40$ ) with no detectable difference between treatments $\left(N_{1}=1, N_{2}=39\right)$.

plants were made early in the next growing season (10 June 1982). Since leaf petioles were numbered from the base of the ramet up, and since leaf scars were persistent, the natality, condition, and mortality of individual leaves could be followed throughout the experiment. "Old leaves" refers to mature leaves that were present at the previous sampling date, and "new leaves" represents leaves that had initiated since the previous sampling date.

\section{RESULTS}

\section{Experimental exclusion: effect over season}

Insect herbivory significantly suppressed in situ plant performance. Plants in the rotenone treatment had lower foliage damage, more leaves, and greater leaf area; they produced more fruits than plants in the control did (Table 1). Multivariate statistics were used to test plant performance as described by the seven vegetative parameters, and to evaluate the degree to which the treatments differed.

The analysis of changes between treatment and control over the 8-wk growing period led to four main conclusions. First, the overall difference in performance between the rotenone treatment and the control was highly significant (Table 1). After a $\log (x+1)$ transformation of the seven variables had eliminated heterogeneity in the covariance matrix (Box's $M=$ $25.77, \mathrm{df}=21, P=.0824$ ), Hotelling's $T^{2}$ test for multiple comparisons (Cooley and Lohnes 1971, Harris $1975)$ was highly significant $\left(T^{2}=145.68 ; \mathrm{df}=7,10\right.$; $P<.001)$.

Second, both Wilk's Lambda and univariate $F$ tests indicated that six of the seven variables differed significantly $(P<.02)$ over the season between treatment and control. The six were height, number of basal leaves, damage to basal leaves, number of cauline leaves, cauline leaf area, and damage to cauline leaves.

Third, 6 of the 21 coefficients in the matrix for group correlation were significant $(P \leq .01)$. The six relationships were: (1) plant height with number of cauline leaves $(r=0.822)$, (2) plant height with area of cauline leaves $(r=0.817)$, (3) area of basal leaves with damage to basal leaves $(r=0.766)$, (4) area of basal leaves with area of cauline leaves $(r=0.636)$, (5) number of basal leaves with area of basal leaves $(r=0.562)$, and (6) number of basal leaves with area of cauline leaves $(r=$ 0.604).

Fourth, discriminant analysis of the measured variables (Table 2, Cooley and Lohnes 1971, Klecka 1975) established that the rotenone-protected plants and the control plants formed highly distinctive groups. Of the total variation, $90.1 \%$ could be explained by the discriminant function (Wilk's Lambda $=0.099, \chi^{2}{ }_{6}=$ $28.91, P \leq .001)$. Both the value of the coefficients and the correlation of individual variables with the dis-

TABLE 2. Results of stepwise canonical discriminant analysis on $\log (x+1)$-transformed change in parameter value over the growing season (31 May-30 July 1981; First Streamlet site, Copper Creek, Gothic, Colorado).

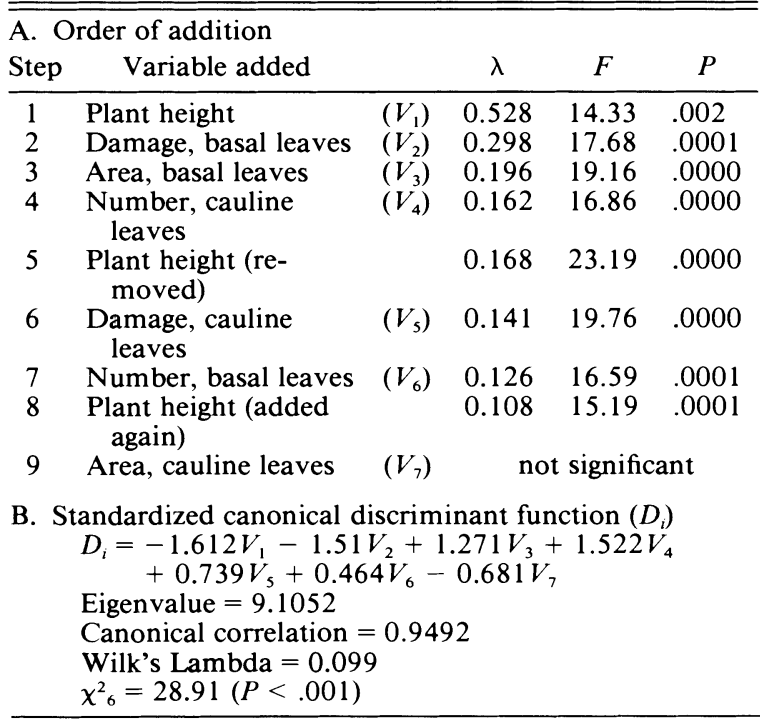


TABLE 3. Plant traits early in the subsequent season (10 June 1982) on marked individuals of Cardamine cordifolia in the rotenone herbivore-exclusion experiment carried out at the First Streamlet site, Copper Creek drainage, Gothic, Colorado.

\begin{tabular}{|c|c|c|c|c|c|c|}
\hline \multirow[b]{2}{*}{ Trait } & \multicolumn{3}{|c|}{ Control } & \multicolumn{3}{|c|}{$\begin{array}{l}\text { Herbivore } \\
\text { exclusion }\end{array}$} \\
\hline & $N$ & $\bar{x}$ & $\mathrm{SE}$ & $N$ & $\bar{x}$ & SE \\
\hline $\begin{array}{l}\text { Plants with basal } \\
\text { leaves only }\end{array}$ & 9 & & & 9 & & \\
\hline $\begin{array}{l}\text { Plants with stems } \\
\text { Stems/plant } \\
\text { Height of stems }\end{array}$ & $\begin{array}{l}5 \\
9\end{array}$ & 0.5 & 0.22 & $\begin{array}{l}7 \\
9\end{array}$ & 1.1 & 0.31 \\
\hline $\begin{array}{c}\text { present } \\
\text { Leaves/plant }\end{array}$ & $\begin{array}{l}7 \\
5\end{array}$ & $\begin{array}{l}2.8 \\
4.6\end{array}$ & $\begin{array}{l}0.77 \\
1.04\end{array}$ & $\begin{array}{r}12 \\
7\end{array}$ & $\begin{array}{l}2.9 \\
9.3\end{array}$ & $\begin{array}{l}0.81 \\
1.68\end{array}$ \\
\hline $\begin{array}{l}\text { Reproductive } \\
\text { Stems with flower } \\
\text { buds }\end{array}$ & 0 & & & 2 & & \\
\hline $\begin{array}{l}\text { Insects } \\
\text { Plants with any } \\
\text { damage } \\
\text { Chrysomelids observed }\end{array}$ & $\begin{array}{l}1 \\
0\end{array}$ & & & $\begin{array}{l}1 \\
0\end{array}$ & & \\
\hline
\end{tabular}

criminant function suggest that the four most important measured traits that distinguished protected and unprotected plants were, in order: (1) plant height, (2) number of cauline leaves, (3) damage to basal leaves, and (4) area of basal leaves (Table 2).

The experimental plants were reexamined on 10 June 1982. Differences persisted between the control plants and the plants protected by rotenone in the previous season, and the treatments affected performance in 1982 (Table 3).

\section{Temporal patterns of leaf dynamics}

A significant difference in damage between rotenoneprotected and control plants was established within the 1 st $2 \mathrm{wk}$ of the experiment (Fig. 1A). By this time, the total leaf area damaged on control plants that were used by insects, although seemingly low $\left(1.7 \mathrm{~cm}^{2}\right)$, was 4.2-fold greater than the damaged area of rotenoneprotected plants. The increase in insect damage on control plants was greatest between 14 June and 1 July (weeks 2-4), before the midpoint of the growing season (Fig. 2, "All"). The largest increment in plant height for protected plants also occurred during the same 2-wk period (Fig. 1B). The total leaf area on the control plants stopped increasing after the $1 \mathrm{st} 2 \mathrm{wk}$, whereas the leaf area continued to accumulate on the rotenonetreated plants throughout the growing season (Fig. 1C). Thus, the experimental reduction of herbivory caused large increments in overall plant stature and in total photosynthetic area. Furthermore, the pattern was established within 2 wk and without defoliation levels of herbivory.

Determination of the fate of individual leaves allowed identification of the dynamics underlying the increase in leaf area, and provided information on the phenology of the interaction. The key processes in the increase in leaf area with the reduction of herbivory were as follows. First, leaf longevity increased when herbivory decreased. The number of old, mature leaves persisting and surviving, both cauline and basal, was significantly higher on plants protected with rotenone than on controls (Fig. 3). Second, the initiation of new leaves was higher on rotenone-protected plants. In the cauline position, the initiation of new leaves was higher on rotenone-sprayed plants, but declined at the same rate over time in both treatments (Fig. 3A). In the basal position, new-leaf initiation after mid-June was consistently higher on rotenone-protected plants than on control plants (Fig. 3). By August, the production of new basal leaves was six times higher on rotenoneprotected than on control-exposed plants (Fig. 3B). Third, the growth of individual leaves could not account for the difference in total leaf area between treatments. Rotenone-protected and control plants had similar leaf-expansion rates for both age-classes of leaves in both positions (Fig. 4). Finally, it is interesting that old leaves experienced a relatively consistent rate of
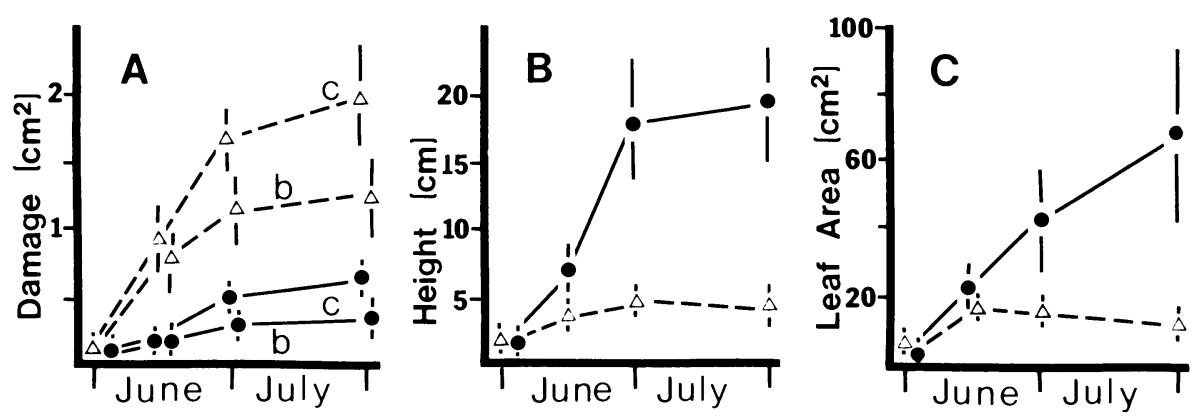

Fig. 1. Plant response by $C$. cordifolia $(\bar{x}, \mathrm{SE})$ to exclusion of insects by rotenone spray from 31 May to 1 August 1981 at First Streamlet, Copper Creek drainage, Gothic, Colorado. $\triangle$ water spray control; $\bullet$ rotenone spray exclusion. A. Cumulative leaf area $\left(\mathrm{cm}^{2}\right)$ damaged for both cauline leaves (c) and basal leaves (b); B. Plant height (cm); C. Total leaf area per plant $\left(\mathrm{cm}^{2}\right)$. 
A. Cauline

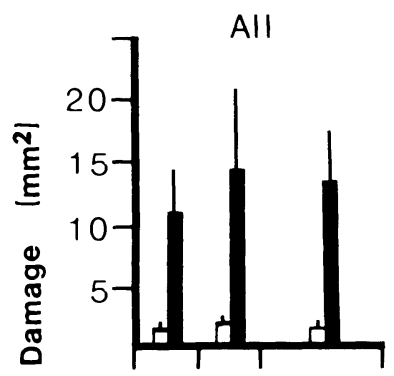

B. Basal

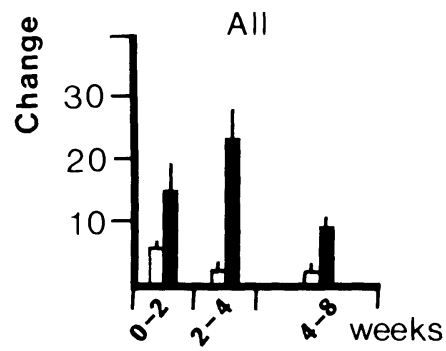

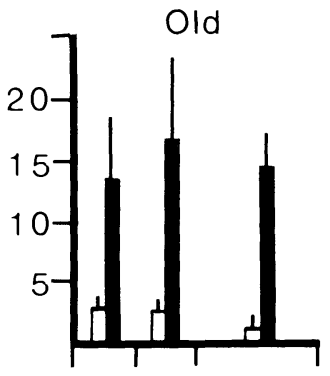
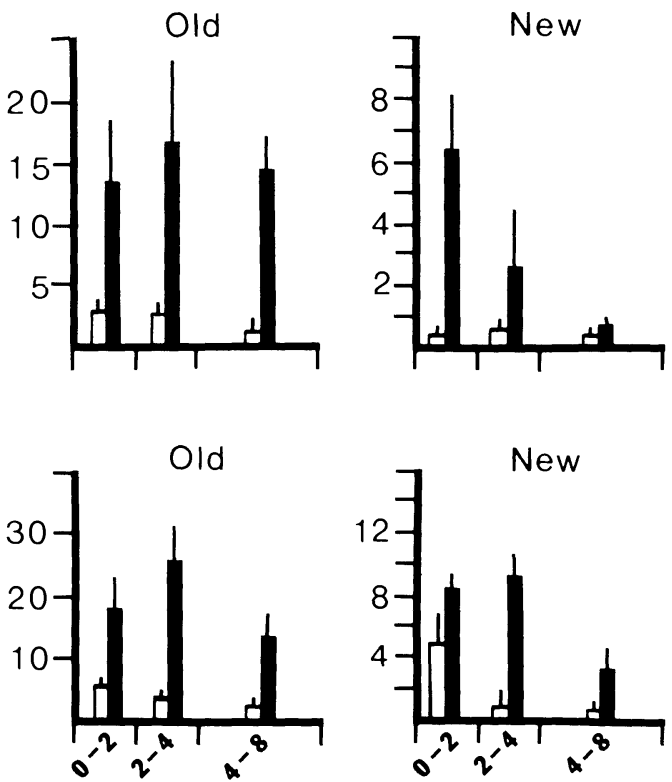

FIG. 2. Insect damage for each indicated time interval (area lost per leaf per plant: $\bar{x}$, SE) by treatment ( $\mathbf{\square}$ water spray control; $\square$ rotenone herbivore exclusion) for all leaves and subdivided by leaf age, where old = present at last sampling date, new $=$ expanded since last observation. A. Cauline leaves, B. Basal leaves.

loss over the season. However, new cauline leaves experienced less insect pressure as the growing season progressed (Fig. 2).

\section{Discussion}

The results suggest that herbivory had a significant, adverse impact on plant growth and fruit production
(Tables 1, 2, and 3), although damage was well below defoliation levels (Fig. 1). The main alternate hypothesis, that rotenone stimulated plant growth, appears to be unlikely. Rotenone is a naturally occurring isoflavonoid with an isopentenyl substitution, not a nitrogen-containing alkaloid; it is known to interfere with the NADH-dependent dehydrogenase step of the mi-

\section{A. Cauline}

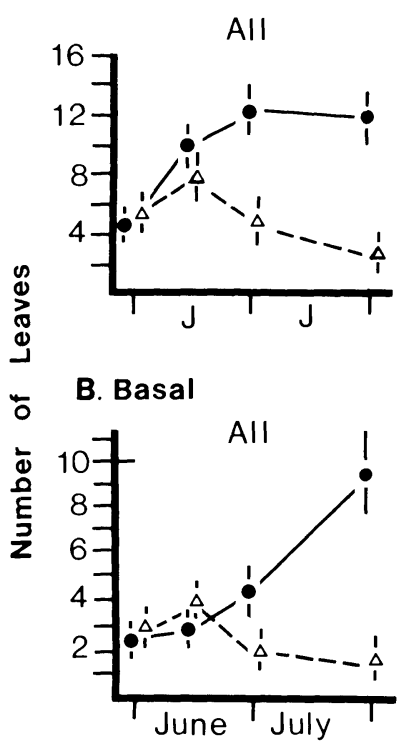

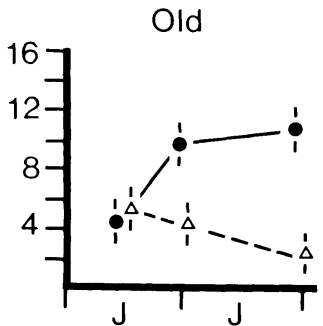
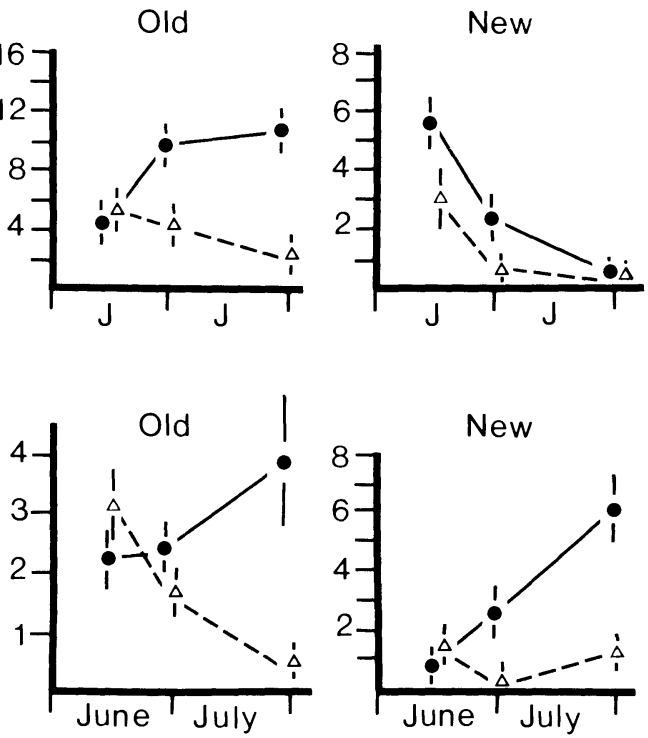

FIG. 3. Number of cauline (A) and basal (B) leaves per plant ( $\bar{x}, \mathrm{SE})$ over the growing season by treatment $(\Delta$ water spray control, i.e., with insects; - rotenone herbivore exclusion). Leaf age as in Fig. 2. 
A. Cauline

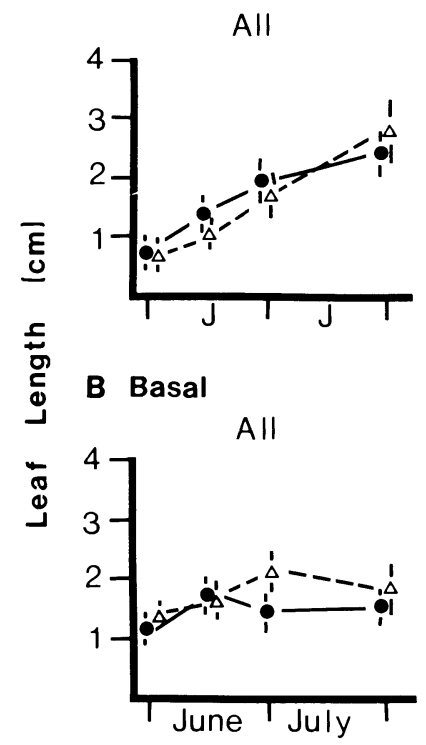

Old
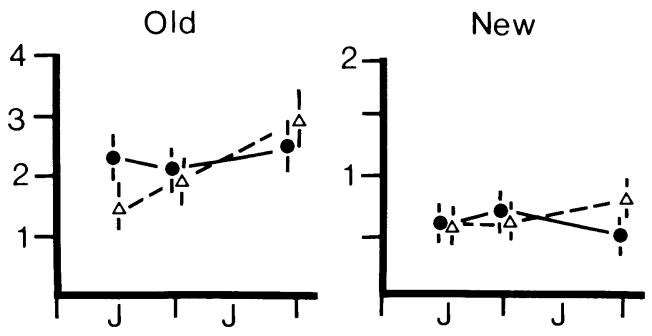

Old

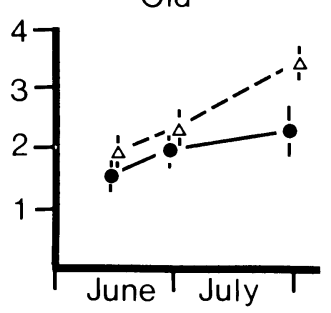

New

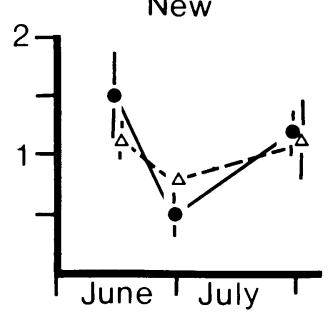

FIG. 4. Length of cauline (A) and basal (B) leaves ( $\bar{x}, \mathrm{SE})$ over the growing season by treatment ( $\triangle$ water spray control, i.e., with insects; rotenone herbivore exclusion). Leaf age as in Fig. 2.

tochondrial respiratory chain in insects (Harborne 1979). Direct effects of polyphenolics, such as rotenone, on plant performance are more likely to be negative than positive.

Multivariate statistical analysis suggested that significant plant response to the reduction of herbivory was a complicated, interrelated syndrome of changes (Table 2). The difference in leaf area between treatment and control plants (Fig. 1C) was due to the increase in the numbers of new leaves and of surviving mature leaves (Fig. 3), and to the decrease in damaged leaf area (Fig. 1A); the difference was not due to any increase in leaf size (Fig. 4). The decreased rate of use of new cauline leaves implies that insects fed on old leaves in preference to new ones, as old leaves became available. This pattern may be related to the decrease in glucosinolate concentration as leaves age (Louda and Rodman 1983a). The change in insect damage was measured on a per-leaf basis, so insect-consumption estimates were independent of the availability of new leaves.

Insect herbivory changed the dynamics of leaf survival and initiation. Both leaf initiation and leaf survival increased as herbivore utilization decreased (Fig. 3). These changes led to the significant changes in the numbers and the areas of leaves (Figs. $1 \mathrm{C}$ and 3). This outcome for leaf number, leaf distribution, total leaf area, and leaf dynamics could not be attributed to differences in herbivory without the experimental exclusion.

Estimates of herbivory based solely on missing or damaged leaf area present several problems. Such measurements tend to overestimate the tissue removed by beetles, since holes on small leaves grow as leaves expand (Reichle et al. 1973). However, the measure does not overestimate the sum of direct removal plus indirect loss of photosynthetic area attributable to insect feeding. (Since leaf dimensions remained similar in the two treatments [Fig. 4], leaf expansion increased small early holes into much larger later reductions in photosynthetic area per leaf.) Furthermore, measurement of missing leaf area underestimates the amount of photosynthetic area lost to herbivory by complete removal of young leaves and by aborted leaf initiation. It is evident here that measuring the missing or damaged leaf area would not clearly demonstrate the cost of insect herbivory and its effect on plant size, plant growth, leaf initiation, leaf survival, and fruit production.

These observations may exemplify many crucifercrucivore interactions. The Cruciferae are utilized by a diverse insect fauna (e.g., Bonnemaison 1965, Root 1973). Damage to mustards by chrysomelids is common and often severe (Tahvanainen 1972, Tahvanainen and Root 1972, Hicks and Tahvanainen 1974, Lipa 1974, Gerber and Obadofin 1981). Also, the specific interaction of Phaedon and Cardamine appears to be consistent in two separate geographic regions (central United States and western Europe): $P h$. cochleariae Fabr. feeds on C. amara L. in Denmark (Nielsen 1978).

Recent experimental analysis of another, similar interaction between chrysomelids and forbs has produced parallel results (see Whittaker 1982). In greenhouse experiments, the chrysomelid Gastrophysa viridula caused significant damage to the polygonaceous biennials Rumex crispus and $R$. obtusifolius 
(Bentley and Whittaker 1979). Even at low densities, the beetle decreased seed number or seed dry mass, or both, for the two species in the field (Bentley et al. 1980). A subsequent field test also indicated that grazing influenced both plant performance and plant occurrence (Whittaker 1982), as seen here; however, the effect of herbivory on leaf dynamics was not examined.

My results address Janzen's (1979:342) question, "How does one measure the impact of herbivory?" Herbivory by adult chrysomelids was responsible for a $25 \%$ reduction in leaf area. This reduction, which was nonlinear, was sufficient to change leaf dynamics and plant growth parameters, and to suppress seed reproduction. The causal relationship between these outcomes and herbivory would not be evident from quantification of the missing leaf area. Static observational data could also lead to misleading conclusions in an analysis of the ecology of the life spans of leaves. Finally, my study substantiates suggestions (Harper 1969, Harris 1973, Whittaker 1979, Louda 1982, 1983) that: (1) patterns of chronic insect consumption can be critical in determining occurrence, stature, or seed reproduction of small perennial plants under natural conditions, and (2) these interactions cannot be adequately assessed without experiments that exclude insect herbivores.

\section{ACKNOWLEDGMENTS}

Insects were identified through the United States Department of Agriculture Insect Identification Bureau, Agricultural Research Service, Beltsville, Maryland. D. W. Inouye loaned me the leaf-area meter. Discussions with A. J. Chester, D. R. Colby, S. N. Handel, M. E. Hay, K. R. McKaye, H. A. Mooney, D. E. Lincoln, J. E. Rodman, and E. E. Werner were important at various stages. I am particularly grateful to A. J. Chester for his assistance with the statistical analysis. I appreciate the support provided for this work by the F. B. and E. D. Brown Postdoctoral Fellowship in Botany, Yale University, a Sigma Xi Grant-in-Aid, and National Science Foundation grants DEB 80-11106 (with J. E. Rodman) and DEB 82-07965.

\section{Literature Cited}

Barrell, J. 1969. Flora of the Gunnison Basin: Gunnison, Saguache and Hinsdale counties, Colorado. Natural Lands Institute, Rockford, Illinois.

Bentley, S., and J. B. Whittaker. 1979. Effects of grazing by a chrysomelid beetle, Gastrophysa viridula, on competition between Rumex obtusifolius and Rumex crispus. Journal of Ecology 67:79-90.

Bentley, S., J. B. Whittaker, and A. J. C. Malloch. 1980. Field experiments on the effects of grazing by a chrysomelid beetle (Gastrophysa viridula) on seed production and quality in Rumex obtusifolius and Rumex crispus. Journal of Ecology 68:671-674.

Bonnemaison, L. 1965. Insect pests of crucifers and their control. Annual Review of Entomology 10:233-256.

Cantlon, J. E. 1969. The stability of natural populations and their sensitivity to technology. Brookhaven Symposia in Biology 22:197-205.

Chabot, B. F., and D. J. Hicks. 1982. The ecology of leaf life spans. Annual Review of Ecology and Systematics 13:229259.

Chew, F. S. 1975. Coevolution of pierid butterflies and their cruciferous foodplants. I. The relative quality of available resources. Oecologia (Berlin) 20:117-127.

1977. Coevolution of pierid butterflies and their cruciferous foodplants. II. The distribution of eggs on potential foodplants. Evolution 31:568-579.

Cooley, W. W., and P. R. Lohnes. 1971. Multivariate data analysis. John Wiley and Sons, New York, New York, USA.

Dyer, M. I., J. K. Detling, D. C. Coleman, and D. W. Hilbert. 1982. The role of herbivores in grasslands. Pages 255-295 in J. R. Estes, R. J. Tyrl, and J. B. Brunken, editors. Grasses and grasslands: systematics and ecology. University of Oklahoma Press, Norman, Oklahoma, USA.

Gerber, G. H., and A. A. Obadofin. 1981. The suitability of nine species of Cruciferae as hosts for the larvae of the red turnip beetle, Entomoscelis americana (Coleoptera: Chrysomelidae). Canadian Entomologist 113:407-413.

Harborne, J. B. 1979. Flavonoid pigments. Pages 619-655 in G. A. Rosenthal and D. H. Janzen, editors. Herbivores: their interaction with secondary plant metabolites. Academic Press, New York, New York, USA.

Harcourt, D. G. 1970. Crop life tables as a pest management tool. The Canadian Entomologist 102:950-955.

Harper, J. L. 1969. The role of predation in vegetation diversity. Brookhaven Symposia in Biology 22:48-62.

. 1977. The population biology of plants. Academic Press, New York, New York, USA.

Harrington, H. D. 1954. Manual of the plants of Colorado. Sage Books, Denver, Colorado, USA.

Harris, P. 1973. Insects in the population dynamics of plants. Pages 201-210 in H. F. van Emden, editor. Insect/plant relationships. Blackwell Scientific Publications, Oxford, England.

Harris, R. J. 1975. A primer of multivariate statistics. Academic Press, New York, New York, USA.

Hicks, K. L., and J. O. Tahvanainen. 1974. Niche differentiation by crucifer-feeding flea beetles (Coleoptera: Chrysomelidae). American Midland Naturalist 91:406-423.

Hodkinson, I. D., and M. K. Hughes. 1982. Insect herbivory. Chapman and Hall, London, England.

Janzen, D. H. 1979. New horizons in the biology of plant defenses. Pages 331-350 in G. A. Rosenthal and D. H. Janzen, editors. Herbivores: their interaction with secondary plant metabolites. Academic Press, New York, New York, USA.

Klecka, W. R. 1975. Discriminant analysis. Pages 434-464 in N. H. Nie, C. H. Hull, J. G. Jenkins, K. Steinbrenner, and D. H. Bent, editors. Statistical package for the social sciences. Second edition. McGraw-Hill, New York, New York, USA.

Lipa, J. 1974. Survey and study of insects associated with cruciferous plants in Poland and surrounding countries. Final report (E2 1-ENT-26, FG-PO-248). Institute of Plant Protection, Laboratory of Biological Control, Poznan, Poland.

Louda, S. M. 1982. Distribution ecology: variation in plant recruitment over a gradient in relation to insect seed predation. Ecological Monographs 52:25-41.

1983. Seed predation and seedling mortality in the recruitment of a shrub, Haplopappus venetus Blake (Asteraceae), along a climatic gradient. Ecology 64:511-521.

Louda, S. M., and J. E. Rodman. 1983a. Ecological patterns in the glucosinolate content of a native mustard, Cardamine cordifolia, in the Rocky Mountains. Journal of Chemical Ecology 9:397-422.

Louda, S. M., and J. E. Rodman. 1983b. Concentration of glucosinolates in relation to habitat and insect herbivory for the native crucifer Cardamine cordifolia. Biochemical Systematics and Ecology 11:199-207.

Manley, G. V., J. W. Butcher, and J. E. Cantlon. 1975. Relationship of insects to distribution and abundance of $\mathrm{Me}$ - 
lampyrum lineare (Scrophulariaceae). Pedobiologia 15:385404.

Mattson, W. J., and N. D. Addy. 1975. Phytophagous insects as regulators of forest primary production. Science 190:515-522.

McNaughton, S. J. 1979. Grazing as an optimization process: grass-ungulate relationships in the Serengeti. American Naturalist 113:691-703.

Morrow, P. A., and V. C. LaMarche. 1978. Tree ring evidence for chronic insect suppression of productivity in subalpine Eucalyptus. Science 201:1244-1246.

Nielsen, J. K. 1978. Host plant discrimination within Cruciferae: feeding responses of four leaf beetles (Coleoptera: Chrysomelidae) to glucosinolates, cucurbitacins and cardenolides. Entomologia Experimentalis et Applicata 24:4154.

Owen, D. F., and R. G. Wiegert. 1976. Do consumers maximize plant fitness? Oikos 27:488-492.

Parker, M. A. 1982. Association with mature plants protects seedlings from predation in an arid grassland shrub. Oecologia (Berlin) 53:276-280.

Parker, M. A., and R. B. Root. 1981. Insect herbivores limit habitat distribution of a native composite, Machaeranthera canescens. Ecology 62:1390-1392.

Rausher, M. D. 1981. Host plant selection by Battus philenor butterflies: the roles of predation, nutrition, and plant chemistry. Ecological Monographs 51:1-20.

Rausher, M. D., and P. Feeny. 1980. Herbivory, plant density, and plant reproductive success: the effect of Battus philenor on Aristolochia reticulata. Ecology 61:905-917.

Reichle, D. E., J. R. Goldstein, R. I. Van Hook, and C. I. Dodson. 1973. Analysis of insect consumption in a forest canopy. Ecology 54:1076-1084.

Rockwood, L. L. 1973. The effect of defoliation on seed production in six Costa Rican tree species. Ecology 54: 1363-1369.
Root, R. B. 1973. Organization of a plant-arthropod association in simple and diverse habitats: the fauna of collards (Brassica oleraceae). Ecological Monographs 43:95-124.

Simberloff, D., B. J. Brown, and S. Lowrie. 1978. Isopod and insect root borers may benefit Florida mangroves. Science 201:630-632.

Stenseth, N. Chr. 1978. Do grazers maximize individual plant fitness? Oikos 31:299-306.

Tahvanainen, J. O. 1972. Phenology and microhabitat selection of some flea beetles (Coleoptera: Chrysomelidae) on wild and cultivated crucifers in central New York. Entomologia Scandinavica 3:120-138.

Tahvanainen, J. O., and R. B. Root. 1972. The influence of vegetational diversity on the population ecology of a specialized herbivore, Phyllotreta cruciferae (Coleoptera, Chrysomelidae). Oecologia (Berlin) 10:321-346.

Wallace, M. M. H. 1961. Enhanced plant-growth with two systemic insecticides. Nature 191:513-514.

Waloff, N., and O. W. Richards. 1977. The effect of insect fauna on growth, mortality and natality of broom, Sarothamnus scoparius. Journal of Applied Ecology 14:787798.

Whittaker, J. B. 1979. Invertebrate grazing, competition and plant dynamics. Pages 207-222 in R. M. Anderson, B. D. Turner, and L. R. Taylor, editors. Population dynamics. British Ecological Society Symposium Number 20. Blackwell Scientific Publications, Oxford, England.

1982. The effect of grazing by a chrysomelid beetle, Gastrophysa viridula, on growth and survival of Rumex crispus on a shingle bank. Journal of Ecology 70:291-296.

Wiegert, R. G., and D. F. Owen. 1971. Trophic structure, available resources and population density in terrestrial vs. aquatic ecosystems. Journal of Theoretical Biology 30:6981 . 